\title{
An Empirical Study on English Learning Motivation for Non-English Majors
}

\author{
Lili YANG \\ City College, Wuhan University of Science and Technology \\ Wuhan, China \\ E-mail: 17150465@qq.com
}

Keywords: English Learning Motivation; Motivation Types; College English Graded Education

\begin{abstract}
The whole research is an empirical study of English learning motivation for different levels non-English majors, aiming to explore the correlations between students' learning motivation and their English achievement under graded education. From the results of our questionnaire investigation, we can draw a conclusion that in Wuhan Textile University, non-English majors have strong instrumental motivation in English learning. Situational motivation is lower than instrumental motivation and the cultural motivation ranks the last. Through independent t-test, the author summarizes that the advanced class gains higher mean than the general class in cultural motivation. It means that cultural motivation is positively correlated with students' English achievement, while situational motivation has negative impact on students' proficiency of English.
\end{abstract}

\section{Introduction}

In recent years, in China, more and more scholars have carried out a lot of empirical studies on motivation taking college students as subjects. Many researchers paid a great deal of attention to the research focus, which changed from pure motivation research to the influence of motivation on achievements and the correlation among various learners factors. [1] Wu Yi'an (1993) put forward that motivation is the important individual factors for English learning achievement. The students who have stronger learning motivation, they will get better results. The study conducted by Wen Qiufang (2001) is concerned with the investigation on the development model of individual learner variables. [2 ] According to the findings, she reported that the relationship among the three variables have higher stability. [3] Motivations influence beliefs and learning strategies and beliefs also have impact on learning strategies. Moreover, she divided the motivation into surface motive and deep motive. Qin Xiaoqing and Wen qiufang (2002) made the investigation of different attributions of motivation, and the study explains that attribution has great impact on learning motivation directly. [4] The present study attempts to deal with the following questions: 1) What are the English learning motivations of the different level students under the graded education? Are there any differences? 2) What are the correlations between students' learning motivation and their English achievement under graded education?

\section{Methodology}

Subjects

The subjects in the present study are 193 sophomore non-English majors of Wuhan Textile University from different majors, including Economics Department, Medical Department, Philosophy Department, School of Law, Software Department and Physics Department. Their average age is 20. Most of the subjects have learnt English from primary school. These subjects are respectively from 3 general classes and 3 advanced classes. Among these subjects, male students comprised about $45 \%$ and female contained around 55\%, they come from different family background. All the subjects are made the investigation of "English learning motivation" by the means of questionnaire. 
TABLE 1 THE General Description of THE SubJeCts

\begin{tabular}{|l|l|l|l|l|l|l|}
\hline Class & Gender & NO. & Per. & Background & NO. & Per. \\
\hline $\begin{array}{l}\text { General } \\
\text { Class }\end{array}$ & Male & 48 & 54.5 & City & 62 & 70.4 \\
\cline { 2 - 7 } & Female & 40 & 45.5 & Village & 26 & 29.6 \\
\hline $\begin{array}{l}\text { Advanced } \\
\text { Class }\end{array}$ & Male & 43 & 47.8 & City & 65 & 72.2 \\
\hline & Female & 47 & 52.2 & Village & 25 & 27.8 \\
\hline
\end{tabular}

\section{Instruments}

In this study, the research instrument is a self-report Likert Scales one. The instrument refers to subjects' opinions by five-point Likert Scales representing from 'strongly agree' to 'strongly disagree'. Each answer has its corresponding score.

\section{Data Collection and analysis}

Data collection was carried out by means of the questionnaire. The author collected much motivation materials, especially about college students' English learning motivation. Based on the previous studies and author's own understanding, an outline about the survey questions and the research methodology are presented. As to the questionnaires, they were distributed and collected to the subjects during the regular class sessions in May, 2013. 193 sophomore non-English majors of Wuhan Textile University have participated in this questionnaire survey which concerns "English learning motivation". After the collection of the questionnaires, the data obtained were computed into the computer. The data analysis was carried out with the help of SPSS 18.0 (Statistical Package for Social Science).

\section{Results and Discussion}

Analysis of the Results of the Differences of Motivation Types

In order to analysis the differences of motivation types between the general class and the advanced class, independent T-test is conducted and the results are listed in the following tables.

TABLE 2 THE DIFFERENCES OF MOTIVATION TYPES BETWEEN THE GENERAL CLASS AND THE ADVANCED CLASS

\begin{tabular}{|l|l|l|l|l|l|l|}
\hline \multirow{2}{*}{ Motivation } & \multicolumn{2}{|l|}{ Advanced Class } & \multicolumn{2}{l|}{ General Class } & \multirow{2}{*}{ t } & \multirow{2}{*}{ Sig. } \\
\cline { 2 - 5 } & Mean & Std. & Mean & Std. & & \\
\hline $\begin{array}{l}\text { Cultural } \\
\text { motivation }\end{array}$ & 3.262 & .654 & 3.083 & .570 & 2.985 & .003 \\
\hline $\begin{array}{l}\text { Intrinsic } \\
\text { interest }\end{array}$ & 3.321 & .688 & 3.142 & .589 & 2.748 & .004 \\
\hline Going abroad & 3.185 & .834 & 2.977 & .754 & 2.536 & .018 \\
\hline
\end{tabular}

As for cultural motivation, including intrinsic interest and going abroad, the advance class students get higher mean than the general class. It indicates that the advanced class students have more internal interest and positive attitudes in English learning, and they have more desire for going abroad than the general class. At the same time, from the Sig. of the three motivations, we can conclude that there is significance difference between the general class and the advanced class in cultural motivation and intrinsic interest (Sig. $<0.005$ ), while the two class students have little obvious difference in going abroad. It means that the two class students have similar opinion for the motivation of going abroad in English learning. 
TABLE 3 FOUR SUBTYPES’ MOTIVATIONS

\begin{tabular}{|l|l|l|l|l|l|l|}
\hline \multirow{2}{*}{ Motivation } & \multicolumn{2}{|l|}{ Advanced Class } & \multicolumn{2}{l}{ General Class } & \multirow{2}{*}{ t } & \multirow{2}{*}{ Sig. } \\
\cline { 2 - 6 } & Mean & Std. & Mean & Std. & \\
\hline $\begin{array}{l}\text { Instrumental } \\
\text { motivation }\end{array}$ & 3.603 & .476 & 3.580 & .512 & 1.986 & 0.52 \\
\hline $\begin{array}{l}\text { personal } \\
\text { development }\end{array}$ & 3.890 & .685 & 3.764 & .702 & 2.545 & 0.12 \\
\hline $\begin{array}{l}\text { immediate } \\
\text { achievements }\end{array}$ & 3.424 & .735 & 3.489 & .796 & -1.508 & .115 \\
\hline $\begin{array}{l}\text { information } \\
\text { med ium }\end{array}$ & 3.408 & .745 & 3.203 & .749 & 2.967 & .003 \\
\hline $\begin{array}{l}\text { social } \\
\text { responsibility }\end{array}$ & 3.389 & .729 & 3.185 & .746 & 2.826 & .002 \\
\hline
\end{tabular}

Instrumental motivation contains four subtypes' motivations; they are personal development, immediate achievements, information medium and social responsibility. From the mean scores, the two class students have similar score in instrumental motivation, and the advance class students gain better scores in personal development, information medium and social responsibility, while slightly lower scores than the general class in immediate achievement. To be more specific, more and more students begin to aware the importance of English for their future life, they hold strong instrumental motivation to learn English; most of them learn English with the practical purpose, such as passing the examination, applying a better job or live up to parents' expectations). Compared with the general class, more students in the advanced class learn English in order to achieve their individual development; they are aware of the usefulness of English in their future career and regard English as a bridge to develop themselves. However, most general class students' in instrumental motivation is to pass examinations or graduation. From the Sig. of the five motivations, in the motivation of information medium and social responsibility, the two class students exists apparent difference. More advanced class students regard English as a media to obtain various kinds of information, related to learn other subjects; and they also more value social responsibility, but most of general class students are lack of the two motivations.

TABLE 4 SITUATIONAL MOTIVATION AND LEARNING SITUATION

\begin{tabular}{|l|l|l|l|l|l|l|}
\hline \multirow{2}{*}{ Motivation } & \multicolumn{2}{|l|}{ Advanced Class } & \multicolumn{2}{l|}{ General Class } & \multirow{2}{*}{ t } & \multirow{2}{*}{ Sig. } \\
\cline { 2 - 5 } & Mean & Std. & Mean & Std. & & \\
\hline Situational & 2.784 & .807 & 2.975 & .766 & -2.947 & .003 \\
motivation & & & & & & \\
\hline $\begin{array}{l}\text { Learning } \\
\text { situation }\end{array}$ & 2.784 & .807 & 2.975 & .766 & -2.947 & .003 \\
\hline
\end{tabular}

From the statistic of above table, we can notice that there are some differences between the two class students in situational motivation. [5] The general class students attach more attention to learning situation around them; they are more easily influenced by teachers, courses, classes or teaching equipment to some extent. What's more, the results of the independent T-test can also indicate that learning situation is a very important motivation during English learning. All of the teachers, students, courses, learning environment and teaching equipment are key factors during the period of students' learning. The students should make full use of these factors in their English learning and finally improve their proficiency of English.

\section{The Learning Motivation and Learners' Achievement}

In order to examine whether English learning motivation and learners' achievement have the interrelations, correlation analysis was computed. The correlation between two variables is measured through correlation analysis. 


\begin{tabular}{|l|l|l|l|l|}
\hline \multicolumn{2}{|c|}{} & $\begin{array}{l}\text { Cultural } \\
\text { motivation }\end{array}$ & $\begin{array}{l}\text { Situational } \\
\text { motivation }\end{array}$ & $\begin{array}{l}\text { Instrumental } \\
\text { motivation }\end{array}$ \\
\hline \multirow{2}{*}{$\begin{array}{l}\text { CET-4 } \\
\text { scores }\end{array}$} & $\begin{array}{l}\text { Pearson } \\
\text { correlation }\end{array}$ & .196 & -.185 & .032 \\
\cline { 2 - 6 } & Sig. & .000 & .000 & .260 \\
\hline
\end{tabular}

From the results of Table 5, we can conclude that cultural motivation has great impact on students' proficiency of English. It has great positive relationship with students' achievement. Concerning situational motivation, its correlation coefficient is -.185, it means that there exists negative correlation between situational motivation and students' Band Four scores. In other words, students have the stronger situational motivation, the lower scores they may get. The reasons may lie in that students learning English affected external learning situation, such as teachers, textbooks or their classes. [6] Therefore, it is difficult for the students with situational motivation to learn well English. As for instrumental motivation, its correlation coefficient is near 0, so from the results of descriptive statistics, we can clearly see that instrumental motivation has no obvious interrelation with students’ English achievement.

\section{Conclusion}

The present study shows that both cultural motivation and situational motivation have important correlation with students' Band Four achievement, while instrumental motivation has no clear correlation. Among the three motivations, cultural motivation is the most important for students to learn well English, therefore, fostering students' cultural awareness for English teaching is a very important method, and it can promote the quality of English teaching. The limitation of this study is the questionnaires may not be perfect, not cover all types of motivations that students hold, some additional variables may be ignored and missed. Moreover, the future studies on the interrelation between motivation types and English achievement may relate with other variable

\section{References}

[1] Arnett,JJ.Emerging adulthood: A theory of development from the late teens through the twenties. American Psychologist. 2000

[2] O’Malley JM,Chamot AU.Learning Strategies in Second Language Acquisition. Journal of Women s Health . 1990

[3] ZoltánDörnyei. Attitudes, Orientations, and Motivations in Language Learning: Advances in Theory, Research, and Applications[J]. Language Learning. 2003 (S1)

[4] Celuch,K.Student self-identity as a critical thinker:The influence of atti-tudes,attitude strength and normative beliefs. Journal of Marketing Edu-cation . 2009

[5] Atkinson, J.w. \& Raynor, J. Personal, motivation and achievement [M]. USA: Hemisphere Publishing Corporation, 1974.

[6] Zimmerman, B. J,Schunk, D. H.Motivation: An essential dimension of self-regulated learning. Motivation and self-regulated learning: Theory, research and applications. 2008 